\title{
The karyotype of three Brazilian Terrarana frogs (Amphibia, Anura) with evidence of a new Barycholos species
}

\author{
Sérgio Siqueira ${ }^{1 *}$, Odair Aguiar Jr. ${ }^{2}$, André Pansonato ${ }^{3}$, Ariovaldo A. Giaretta ${ }^{4}$, Christine Strüssmann ${ }^{5}$, \\ Itamar Martins $^{6}$ and Shirlei M. Recco-Pimentel ${ }^{1}$ \\ ${ }^{1}$ Departamento de Biologia Celular, Instituto de Biologia, Universidade Estadual de Campinas, \\ Campinas, SP, Brazil. \\ ${ }^{2}$ Departamento de Biociências, Universidade Federal de São Paulo, Santos, SP, Brazil. \\ ${ }^{3}$ Programa de Pós-Graduação em Ecologia e Conservação da Biodiversidade, \\ Universidade Federal de Mato Grosso, Cuiabá, MT, Brazil. \\ ${ }^{4}$ Departamento de Biociências, Instituto de Biologia, Universidade Federal de Uberlândia, Uberlândia, \\ MG, Brazil. \\ ${ }^{5}$ Departamento de Ciências Básicas e Produção Animal, Universidade Federal de Mato Grosso, Cuiabá, \\ MT, Brazil. \\ ${ }^{6}$ Departamento de Biologia, Universidade de Taubaté, Taubaté, SP, Brazil.
}

\begin{abstract}
A recent substantial rearrangement of the 882 described eleutherodactyline frog species has considerably improved the understanding of their systematics. Nevertheless, many taxonomic aspects of the South American eleutherodactyline species remain unknown and require further investigation using morphological, cytogenetic and molecular approaches. In this work, the karyotypes of the Brazilian species Ischnocnema juipoca (Atibaia and Campos do Jordão, SP), Barycholos cf. ternetzi (Uberlândia, MG, and Porto Nacional, TO), and Pristimantis crepitans (Chapada dos Guimarães and São Vicente, MT) were analyzed using Giemsa staining, Ag-NOR labeling, and C-banding techniques. All individuals had a diploid number of 22 chromosomes, but the Fundamental Numbers were different among species. The herein described low chromosome number of Pristimantis crepitans is unique within this genus, suggesting that cytogenetically this species is not closely related either to its congeneric species or to Ischnocnema. In addition, karyotype differences, mainly in the NOR position, clearly distinguished the two Barycholos populations, besides indicating the existence of a so far undescribed species in this genus. A taxonomic review could clarify the systematic position of $P$. crepitans and verify the hypothetic new Barycholos species.
\end{abstract}

Key words: cytogenetics, Barycholos, Ischnocnema, Pristimantis, Ag-NOR, C-banding.

Received: July 18, 2008; Accepted: October 16, 2008.

\section{Introduction}

Recent taxonomic reviews based on molecular data (Frost et al., 2006; Heinicke et al., 2007; Hedges et al., 2008) dramatically changed the long-standing systematics of the "eleutherodactyline" frogs (sensu Frost et al., 2006). Heinicke et al. (2007) proposed four major clades for this anuran group, comprising the species from (1) the Caribbean (Eleutherodactylus), (2) Middle America (Craugastor), (3) Northern South America (Pristimantis), and (4) Southeastern Brazil (Ischnocnema), all of them placed in a single family named Brachycephalidae.

Send correspondence to Shirlei M. Recco-Pimentel. Departamento de Biologia Celular, Instituto de Biologia, Universidade Estadual de Campinas, Caixa Postgal 6109, 13083-863 Campinas, SP, Brazil. E-mail: shirlei@unicamp.br.

*Present affiliation: Departamento de Ciências Biológicas, Universidade Estadual do Sudoeste da Bahia, Jequié, BA, Brazil.
Based on DNA sequences from mitochondrial and nuclear genes of 344 species, Hedges et al. (2008) placed the 882 described species of Brachycephalidae into a new taxon, Terrarana, and classified them into four families, four subfamilies, 24 genera and 11 subgenera. Of those, two families, three subfamilies, six genera, and two subgenera were proposed and named as new taxa. The genera Brachycephalus and Ischnocnema remained in the Brachycephalidae family, a group restricted to the southeastern region of Brazil, as previously suggested by Heinicke et al. (2007). Pristimantis and Barycholos were allocated to the family Strabomantidae, subfamilies Strabomantinae e Holoadeninae, respectively, which are new taxa proposed by Hedges et al. (2008).

Thus far, more than 100 Terrarana species have been cytogenetically studied and reported as having a high de- 
gree of chromosome number variation, ranging from $2 n=18$ to 36 (Bogart, 1991). Considering the arrangements proposed by Hedges et al. (2008), the Craugastor genus has $2 \mathrm{n}=18,20$ and 22 chromosomes, Diasporus $2 \mathrm{n}=18$, Brachycephalus $2 \mathrm{n}=22$, Ischnocnema $2 \mathrm{n}=20,22$ and 30 , Strabomantis $2 \mathrm{n}=20,22,34$ and 35, while Haddadus and Barycholos have $2 \mathrm{n}=22$ chromosomes. The Pristimantis species display the greatest diploid complement variation, with $2 \mathrm{n}=26,30,32,34$ and 36 chromosomes. Genus Eleutherodactylus (sensu Hedges et al., 2008) is also highly variable, with $2 \mathrm{n}=18,22,24,26,28,30$ and 32 chromosomes. Within the four Eleutherodactylus subgenera, Eleutherodactylus (Eleutherodactylus) have $2 \mathrm{n}=18$, 22, 26, 28 and 30, Eleutherodactylus (Euhyas) 2n = 24-32, Eleutherodactylus (Pelorius) $2 \mathrm{n}=30$, and Eleutherodactylus (Syhrophus) 2n = 22 and 30 (Duellman, 1967; Beçak, 1968; Brum-Zorrilla and Sáez, 1968; Bogart, 1970a,b,c, 1973, 1981, 1984, 1991; León, 1970; Beçak and Beçak, 1974; De Lucca and Jim, 1974; De Lucca et al., 1974; DeWeese, 1975; Drewry and Jones, 1976; Savage and DeWeese, 1979, 1980; Green et al., 1980; Miyamoto, 1983, 1984; Kaiser et al., 1994, 1995; Bogart and Hedges, 1995; Savage and Myers, 2002; Siqueira et al., 2004; Campos et al., 2008). Additional cytogenetic studies on Terrarana species could help to improve the current taxonomic and evolutionary knowledge regarding this group.

In the present work, we analyzed two samples of Ischnocnema juipoca, two of Barycholos cf. ternetzi and two of Pristimantis crepitans. This latter species was not yet studied by molecular techniques, being included in genus Pristimantis, family Strabomantidae, based only on its geographic distribution (Hedges et al., 2008). We aimed to increase the number of karyotyped Brazilian Terrarana species and further understand their taxonomy and evolutionary relatedness.

\section{Material and Methods}

Specimens of Ischnocnema juipoca, Barycholos cf. ternetzi and Pristimantis crepitans were sampled under a permit (License no 206/2005 - CGFAU/LIC) issued by IBAMA (Instituto Brasileiro do Meio Ambiente e dos Recursos Naturais Renováveis - Brazilian Institute of the Environment and Natural Renewable Resources). Voucher specimens were deposited in the Museu de Zoologia "Prof. Dr. Adão José Cardoso", at the Universidade Estadual de Campinas (UNICAMP), Campinas, SP, Brazil, and in the Coleção "Célio F. B. Haddad" at the Universidade Estadual Paulista (UNESP), Rio Claro, SP, Brazil (Table 1). The sampling locations where the specimens were surveyed are displayed in Figure 1.

Mitotic chromosomes were obtained from suspensions of intestinal epithelium and testicular cells from animals pre-treated with $2 \%$ colchicine for at least $4 \mathrm{~h}$, as described by King and Rofe (1976) and Schmid (1978). Conventional chromosome staining was performed with 10\% Giemsa solution, Ag-NOR labeling (Howell and Black, 1980), and C-banding (Sumner, 1972), as modified by Siqueira et al. (2008). The slides were examined with a BX60 Olympus microscope and images were captured using the Image Pro-plus 4.5.1 and QCapture 2.81.0 softwares. Chromosomes were measured and classified according to Green and Sessions (1991).

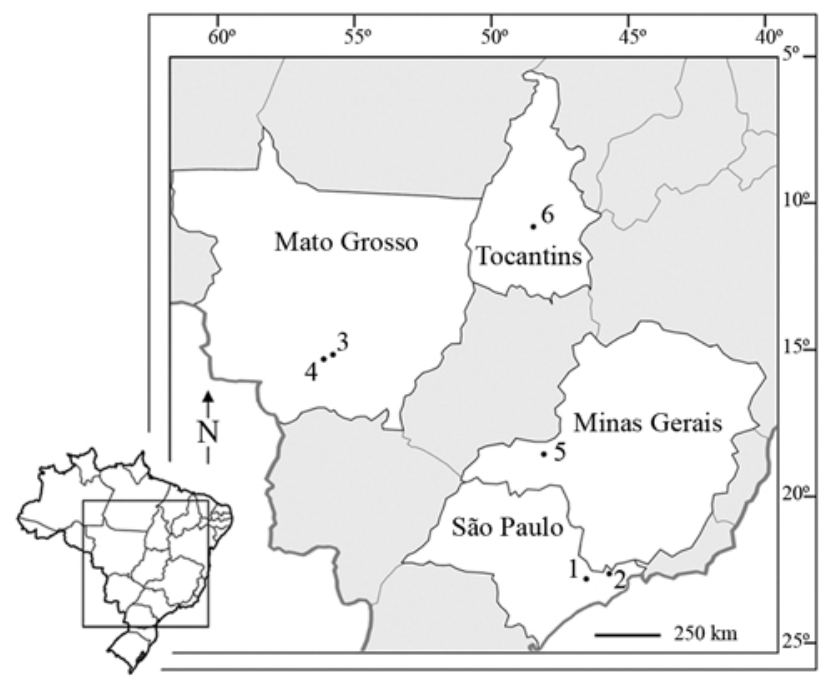

Figure 1 - Map of Brazil showing the sampling sites where the studied frog populations were surveyed. 1: Atibaia, State of São Paulo, Ischnocnema juipoca; 2: Campos do Jordão, State of São Paulo, I. juipoca; 3: Chapada dos Guimarães, State of Mato Grosso, Pristimantis crepitans; 4: São Vicente, Cuiabá, State of Mato Grosso, P. crepitans; 5: Uberlândia, State of Minas Gerais, Barycholos cf. ternetzi; 6: Porto Nacional, State of Tocantins, Barycholos cf. ternetzi.

Table 1 - Voucher specimens, sampling sites and accession numbers.

\begin{tabular}{lcclcc}
\hline Species & Male (n) & Female (n) & Sampling site & ZUEC and CFBH* accession numbers \\
\hline $\begin{array}{l}\text { Ischnocnema juipoca } \\
\text { Pristimantis crepitans }\end{array}$ & 2 & 1 & $\begin{array}{l}\text { Atibaia and Campos do Jordão, State of São } \\
\text { Paulo }\end{array}$ & $13265,13266,9904^{*}$ \\
Barycholos cf. ternetzi & 7 & 2 & $\begin{array}{l}\text { Chapada dos Guimarães and Distrito de São } \\
\text { Vicente, Cuiabá, State of Mato Grosso }\end{array}$ & $14114-14119$ \\
Barycholos cf. ternetzi & - & 2 & Uberlândia, State of Minas Gerais & $13262-13264,13475,13476,14120-14123$ \\
\hline
\end{tabular}

$\mathrm{n}=$ number of specimens analyzed; accession numbers at the Museu de Zoologia "Prof. Adão José Cardoso" (ZUEC), UNICAMP. 


\section{Results}

In all analyzed individuals, the diploid number was 22 chromosomes, but the Fundamental Numbers (FN) discriminated the three species. The FNs were determined as 40 in I. juipoca, 38 in Barycholos cf. ternetzi, and 44 in Pristimantis crepitans (Figures 2-5).

\section{Ischnocnema juipoca}

The karyotypes of the two analyzed I. juipoca populations consisted of five pairs of metacentric chromosomes $(1,6,7,9$ and 10$)$, four pairs of submetacentrics $(2,3,4$ and 5 ) and two pairs of telocentrics (8 and 11) (Figures 2A-C). Secondary constrictions were present on the short arm of pair 3 and occasionally adjacent to the centromere of pair 11 (Figure 2A). Blocks of heterochromatin were detected in the centromeric region of all chromosomes, and in several metaphases there was a faint C-band adjacent to the centromere of pair 11 , coinciding with the secondary constriction, and on the telomere of the short arm of pair 2 as well (Figure 2B). In the telocentric pair 11, the Ag-NOR sites were adjacent to the centromere and coincided with the secondary constriction and the pericentromeric block of heterochromatin (Figures 2A-C).

Unusual size variation of the telocentric pairs was observed, both among metaphases of the same specimen and among different specimens. This size variation was probably due to differences in chromosome compaction and has

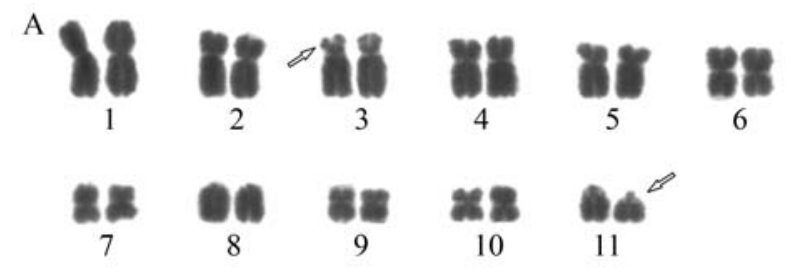

B

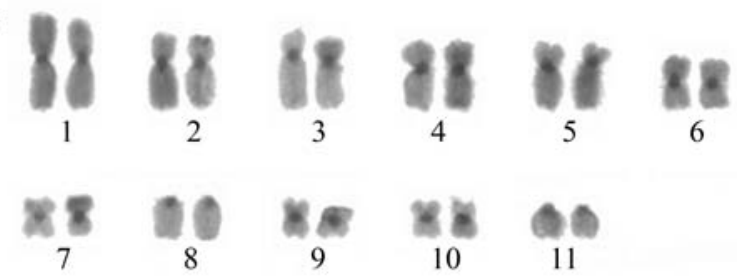

$\mathrm{C}$

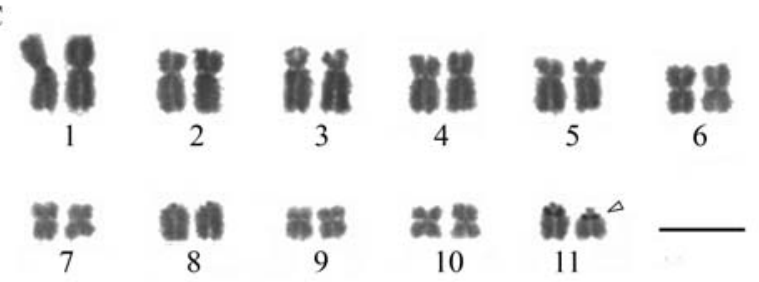

Figure 2 - Karyotype of Ischnocnema juipoca: (a) Giemsa staining; (b) C-banding; (c) Ag-NOR labeling. The arrow indicates secondary constrictions. The arrowheads indicate the NOR coincident with secondary constriction. Bar $=10 \mu \mathrm{m}$. hampered the positioning of these chromosomes in the karyogram, since they could be placed in any position among the last four pairs. Size variation of the telocentric chromosomes was also observed in the Barycholos populations.

\section{Barycholos cf. ternetzi (Uberlândia, MG)}

The karyotype of Barycholos cf. ternetzi consisted of six metacentric (1, 2, 4, 6, 7 and 9), one submetacentric (pair 3), one subtelocentric (pair 5) and three telocentric (8, 10 and 11) pairs (Figures 3A-E). In several metaphases, secondary constrictions were found on the telomere of the NOR-carrying telocentric chromosome 8 (Figures 3A-E). Three distinct NOR patterns were detected: (1) in three specimens, three Ag-NOR sites were observed on the

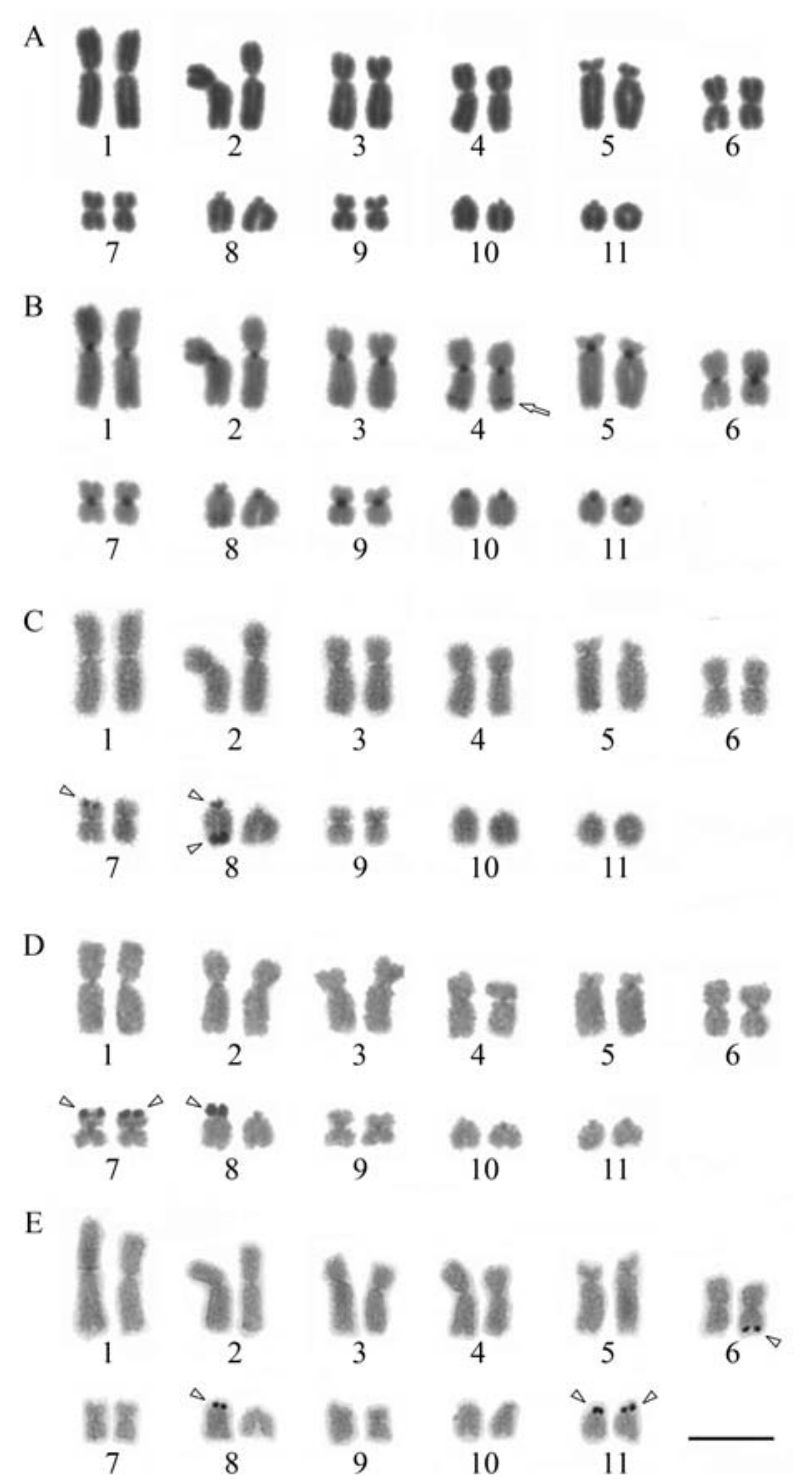

Figure 3 - Karyotype of Barycholos cf. ternetzi (Uberlândia, MG): (a) Giemsa staining; (b) C-banding; (c-e) Ag-NOR staining. The arrow indicates interstitial heterochromatin. The arrowheads indicate NORs. Note the distinct position and number of NORs in $\mathbf{c}, \mathbf{d}$ and $\mathbf{e}$. Bar $=10 \mu \mathrm{m}$. 
telomere of one pair 7 homologue, and two on one pair 8 homologue, one on the centromere and the other on the telomere (Figure 3C); (2) in four specimens, three Ag-NOR sites were found, two on the telomeres of pair 7 and one adjacent to the centromere of one chromosome of pair 8 (Figure 3D); and (3) in two specimens, four Ag-NORs were found, one on the telomere of one pair 6 homologue and one on the centromere of one pair 8 homologue, and two labels on the centromeres of pair 11 (Figure 3E). Heterochromatic blocks were detected in the centromeric region of all chromosomes, and a faint C-band was observed near the telomere on the long arm of pair 4 (Figure 3B).

\section{Barycholos cf. ternetzi (Porto Nacional, TO)}

The Barycholos cf. ternetzi karyotype consisted of six metacentric (1, 2, 4, 6, 7 and 9), one submetacentric (pair 3 ), one subtelocentric (pair 5) and three telocentric $(8,10$ and 11) pairs (Figures 4A-C). Secondary constrictions were found interstitially on pairs 10 and 11 (Figures 4A-C). The Ag-NORs were interstitially located in pairs 10 and 11, coincident with the secondary constrictions (Figure 4C). The NORs were heteromorphic in pair 11. Heterochromatic blocks were limited to the centromeric region of all chromosomes (Figure 4B).

\section{Pristimantis crepitans}

The $P$. crepitans karyotype consisted of eigth pairs of metacentric $(1,2,5,6,8,9,10$ and 11) and three of

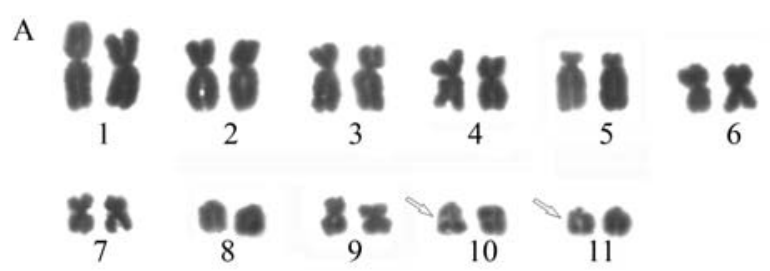

B

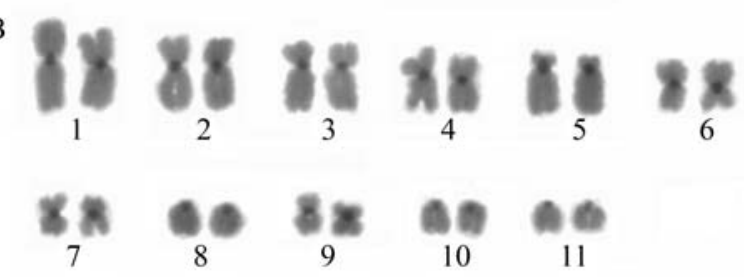

C

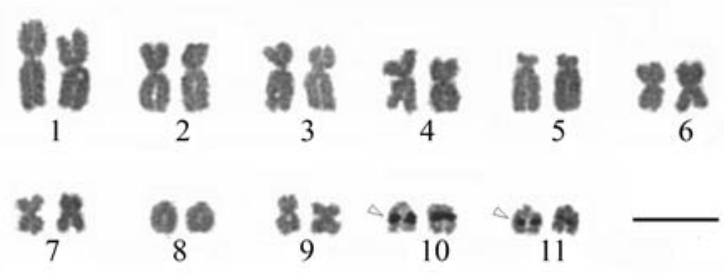

Figure 4 - Karyotype of Barycholos cf. ternetzi (Porto Nacional, TO): (a) Giemsa staining; (b) C-banding; (c) Ag-NOR staining. The arrow indicates secondary constrictions. The arrowheads indicate the NORs coincident with secondary constriction. Bar $=10 \mu \mathrm{m}$. submetacentric chromosomes (3, 4 and 7). Interstitial secondary constrictions were observed on the long arms of pair 7, where the NOR sites were detected (Figures 5A and C). Blocks of strongly stained heterochromatin were located in the centromeric region of all chromosomes (Figure 5B).

\section{Discussion}

The diploid number of 22 chromosomes observed in I. juipoca, Barycholos cf. ternetzi and P. crepitans has also been described for 28 other Terrarana frog species. In this anuran group, $P$. crepitans is the only species with such a low chromosome number occurring in the midwest of Brazil. The species with $2 \mathrm{n}=20$ and 22 are typically distributed in southeastern and southern Brazil, while most Brazilian species of the northern and northeastern regions have $2 \mathrm{n}=30$ and 34 (Bogart, 1973; DeWeese, 1975; Siqueira et al., 2004, Siqueira et al., 2008).

The chromosome morphology and C-banding patterns found in the karyotype of the Barycholos cf. ternetzi specimens from Uberlândia were very similar to those previously described in Gurinhatã specimens (Campos et al., 2008). These two sampling sites are located in the State of Minas Gerais, not very distant from each other. Some small karyotype differences may have resulted from the use of different chromosome preparation techniques and from the classification methods used for karyotype description. Moreover, in the Barycholos specimens from Uberlândia,
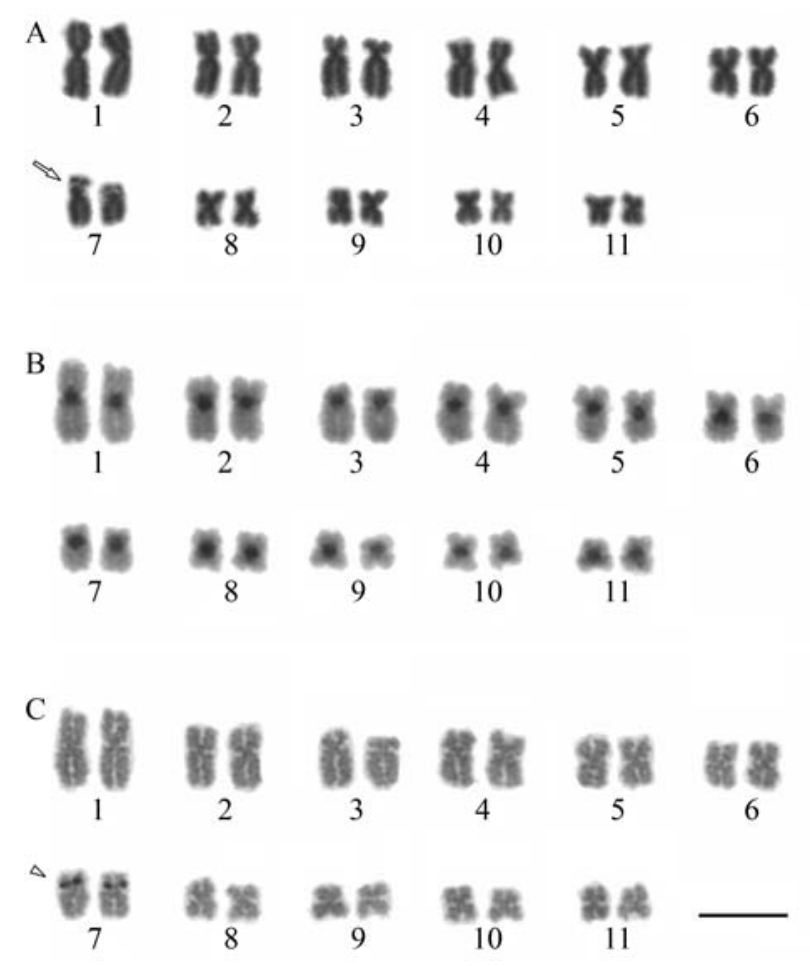

Figure 5 - Karyotype of Pristimantis crepitans: (a) Giemsa staining; (b) $\mathrm{C}$-banding; (c) Ag-NOR staining. The arrow indicates the secondary constriction. The arrowheads indicate the NORs coincident with secondary constrictions. Bar $=10 \mu \mathrm{m}$. 
the only heterochromatic block detected on the long arm of pair 4 corresponded to a band on pair 4 of the C-banded karyotype of Barycholos ternetzi (Gurinhatã), as shown by Campos et al. (2008), although the authors did not explicitly mention this band. In contrast, the karyotype of Barycholos cf. ternetzi from Uberlândia showed variation in number and position of NORs, as also reported for $B$. ternetzi from Gurinhatã by Campos et al. (2008). These authors suggested that the fixed NOR must be that on pair 11. In the present work, we found three additional NOR patterns. Of these, only one was observed on pair 11, indicating that the principal NOR-bearing chromosome is still uncertain.

The variation in number and position of NORlabeling in the two studied Barycholos populations, one by Campos et al. (2008) and the Barycholos cf. ternetzi presented herein, suggests the occurrence of chromosomal rearrangements involving mainly the telomeric regions. In anuran species, transposition of mobile genetic elements, ribosomal cistron amplification, and rDNA reinsertion errors during extra chromosomal amplification of ribosomal cistrons have been suggested as responsible for such NOR variations (Wiley et al., 1989; King et al., 1990; Foote et al., 1991; Schmid et al., 1995; Kaiser, 1996; Lourenço et al., 1998). The variation in NOR number and location may represent an incipient process of species differentiation, and a taxonomic review, including additional methodologies, could clarify if this is indeed a new taxon.

Regarding the Barycholos cf. ternetzi specimens from Porto Nacional, the Ag-NOR labeling was fixed in two chromosome pairs (10 and 11) and located in an interstitial position, differently from the telomeric position observed in the Barycholos cf. ternetzi specimens from Uberlândia. The four analyzed Barycholos cf. ternetzi specimens from Porto Nacional also differed from the $B$. ternetzi from Gurinhatã (Campos et al., 2008). Additionally, the specimens from Porto Nacional did not show the heterochromatic block on the long arm of pair 4 .

In spite of the similar chromosome morphology presented by the two Barycholos cf. ternetzi populations studied, the karyotypic differences, mainly in NOR position and C-banding, indicate the possible existence of two species and call attention to the need of a taxonomic review of these populations. The NOR locations and heterochromatin pattern have been useful to distinguish among different species such as, for example, Scythrophrys (Lourenço et al., 2003a, 2008), Paratelmatobius (Lourenço et al., 2003b, 2008) and Pristimantis dundeei and Pristimantis. aff. dundeei (Siqueira et al., 2008). Moreover, since vocalization and chromosomal features of the topotypical population are unknown, none of the already studied populations can be assigned with certainty to the nominal Barycholos ternetzi.

The data obtained for I. juipoca from Atibaia and Campos do Jordão are in agreement with those described by Campos et al. (2008) for populations from Itatiba and Santa Branca, also in the State of São Paulo. The other karyotyped species of genera Ischnocnema and Brachycephalus, both within family Brachycephalidae, were substantially diverse from those described herein. Those other species, such as I. guentheri, I. parva and B. ephippium, have the same chromosome number as $I$. juipoca $(2 \mathrm{n}=22)$, but no telocentric chromosomes (Siqueira et al., 2004; Ananias et al., 2006), whereas I. holti and I. lactea present a diploid number of 20 chromosomes (De Lucca and Jim, 1974; De Lucca et al., 1974). In addition, in B. ephippium the NOR was located interstitially on the metacentric pair 8, while in I. juipoca it was on the telocentric pair 11 .

Pristimantis crepitans was removed from the synonymy of Eleutherodactylus fenestratus, (Heyer and Muñoz, 1999), where it was originally placed (Lynch, 1980). Hedges et al. (2008) allocated $P$. crepitans to the $P$. peruvianus group, and J. M. Padial (pers. comm. to Hedges et al., 2008) indicated the possibility that both $P$. crepitans and $P$. dundeei might belong to the $P$. conspicillatus group. However, the low chromosome number and the ecological characteristics of $P$. crepitans and $P$. dundeei indicate that these species are not closely related to the other Pristimantis. The putative taxonomic position of the former within genus Pristimantis, as proposed by Heinicke et al. (2007) and Hedges et al. (2008), was based solely on its geographical distribution, since it was never included in any molecular analysis. The low chromosome number $(2 \mathrm{n}=22)$ of $P$. crepitans is commonly found in Ischnocnema and is highly divergent from other known Pristimantis karyotypes, which typically have high chromosome numbers $(2 n=30$ to 34$)$. Unfortunately, the only other Pristimantis species with a low diploid number, $P$. altae with $2 \mathrm{n}=26$ (DeWeese, 1975), was not yet submitted to molecular analysis. On the other hand, a preliminary analysis of spermatozoa ultrastructure indicated great differences between $P$. crepitans and the other Pristimantis species, as well as the studied Ischnocnema species (S. Siqueira S., unpublished data). Pristimantis crepitans is also unique by living in open and xeric habitats in the Cerrado biome, among granitic or arenitic outcrops. These divergences strongly suggest a need of complementary molecular analysis to reassess the recently proposed allocation of $P$. crepitans to genus Pristimantis (Heinicke et al., 2007; Hedges et al., 2008). Therefore, further studies are necessary to clarify the systematic position of these species.

\section{Concluding Remarks}

Major contributions to the understanding of the molecular phylogeny of the South American eleutherodactyline species were recently brought by Frost et al. (2006), Heinicke et al. (2007) and Hedges et al. (2008). However, for Brazilian species there are many unresolved taxonomic aspects which require further investigation us- 
ing a combination of morphological, cytogenetic and molecular techniques. Based on previously reported molecular data (Frost et al., 2006), behavioral studies (Caramaschi and Pombal, 2001), and karyotypes (Campos et al., 2008) it seems conceivable that Barycholos and the already karyotyped Ischnocnema species are close relatives. However, the additional molecular studies of Hedges et al. (2008) indicate that Barycholos is phylogenetically distant from both Ischnocnema and Haddadus binotatus. Therefore, the observed chromosomal similarities might be symplesiomorphies or the result of convergence generated by chromosomal rearrangements, thus not substantiating a hypothesis of close evolutionary relationships between the species I. juipoca and Barycholos.

In the new systematic arrangement for "eleutherodactyline" frogs proposed by Heinicke et al. (2007) and Hedges et al. (2008), mostly based on molecular data, there are still indications of divergences in relation to the available karyological data. Most likely, the divergences are due to the lack of molecular analysis of many of the Brazilian karyotyped species, such as Pristimantis crepitans and $P$. altae. Further molecular and chromosome analyses of Terrarana frogs, including these divergent species, should provide a broader understanding of their evolutionary relatedness and systematic status.

\section{Acknowledgments}

The authors thank Leandro Magrini and Zenilda C. Carvalho for assisting with field work. This research was supported by Coordenação de Aperfeiçoamento de Pessoal de Nível Superior (CAPES; scholarship to SS and PRODOC to CS), Fundação de Amparo à Pesquisa do Estado de São Paulo (FAPESP - grants 06/61738-3 and 01/13341-3), Conselho Nacional de Desenvolvimento Científico e Tecnológico (CNPq - financial support to AAG and SMRP), Fundação de Apoio à Pesquisa do Estado de Minas Gerais (FAPEMIG), and Centro de Pesquisa do Pantanal (CPP).

\section{References}

Ananias F, Giaretta AA and Recco-Pimentel SM (2006) Cytogenetics of Brachycephalus ephippium (Anura, Brachycephalidae) with comments on its relationship to the Bufonidae. Amphibia-Reptilia 27:121-125.

Beçak ML (1968) Chromosomal analysis of eighteen species of Anura. Caryologia 21:191-208.

Beçak ML and Beçak W (1974) Diploidization in Eleutherodactylus (Leptodactylidae-Amphibia). Experientia 30:624-625.

Bogart JP (1970a) Los cromosomas de anfibios anuros del género Eleutherodactylus. Act IV Congr Latin Zool, Caracas, pp 65-78.

Bogart JP (1970b) Cromosomas en algunos géneros de anuros. Act IV Congr Latin Zool, Caracas, pp 79-85.

Bogart JP (1970c) Systematic problems in the amphibian family Leptodactylidae (Anura) as indicated by karyotypic analysis. Cytogenetics 9:369-383.
Bogart JP (1973) Evolution of anuran karyotypes. In: Vial JL (eds) Evolutionary Biology of Anurans. Univ Missouri Press, Columbia, pp 337-49.

Bogart JP (1981) Chromosome studies in Sminthillus from Cuba and Eleutherodactylus from Cuba and Puerto Rico (Amphibia, Leptodactylidae). Life Sci Contr R Ontario Mus 129:1-22.

Bogart JP (1991) The influence of life history on karyotypic evolution in frogs. In: Green DM and Sessions SK (eds) Amphibian Cytogenetics and Evolution. Acad Press, New York, pp 233-258.

Bogart JP and Hedges SB (1995) Rapid chromosome evolution in Jamaican frogs of the genus Eleutherodactylus (Leptodactylidae). J Zool 235:9-31.

Brum-Zorrilla N and Saez FA (1968) Chromosomes of Leptodactylidae (Amphibia, Anura). Experientia 24:969.

Campos JRC, Ananias F, Haddad CFB and Kasahara S (2008) Karyotypic similarity among Barycholos ternetzi and five species of the genus Eleutherodactylus from southeastern Brazil (Anura, Brachycephalidae). Micron 39:151-159.

Caramaschi U and Pombal Jr JP (2001) Barycholos savagei: A junior synonym of Paludicola ternetzi, with notes on development. J Herpetol 35:357-360.

De Lucca EJ and Jim J (1974) Cromossomos de alguns Leptodactylidae. Rev Bras Biol 34:407-410.

De Lucca EJ, Jim J and Foresti F (1974) Chromosomal studies in twelve species of Leptodactylidae and one Brachycephalidae. Caryologia 27:183-192.

DeWeese JE (1975) Chromosomes in Eleutherodactylus (Anura, Leptodactylidae). Mamm Chrom Newsl 16:121-123.

Drewry GE and Jones KL (1976) A new ovoviviparous frog, Eleutherodactylus jasperi (Amphibia, Anura, Leptodactylidae), from Puerto Rico. J Herpetol 10:161-165.

Duellman WE (1967) Additional studies of chromosomes of anuran amphibians. Syst Zool 16:38-43.

Foote DL, Wiley JE, Little DL and Meyene J (1991) Ribosomal RNA gene site polymorphism in Bufo terrestris. Cytogenet Cell Genet 57:196-199.

Frost DR, Grant T, Faivovich J, Bain RH, Haas A, Haddad CFB, De Sa RO, Channing A, Wilkinson M, Donnellan SC, et al. (2006) The Amphibian tree of life. Bull Am Mus Nat Hist 297:1-370.

Green DM and Sessions SK (1991) Nomenclature for chromosomes. In: Green DM and Sessions SK (eds) Amphibian Cytogenetics and Evolution. Acad Press, San Diego, pp 431-432.

Green DM, Bogart JP, Anthony EH and Genner DL (1980) An interactive, microcomputer-based karyotype analysis system for phylogenetic cytotaxonomy. Comput Biol Med 10:219227.

Hedges SB, Duellman WE and Heinicke MP (2008) New World direct-developing frogs (Anura, Terrarana): Molecular phylogeny, classification, biogeography, and conservation. Zootaxa 1737:1-182.

Heinicke MP, Duellman WE and Hedges SB (2007) Major Caribbean and Central American frog faunas originated by ancient oceanic dispersal. Proc Natl Acad Sci USA 104:10092-10097.

Heyer WR and Muñoz AM (1999) Validation of Eleutherodactylus crepitans (Bokermann 1965), notes on the types and type locality of Telatrema heterodactylum 
(Miranda-Ribeiro 1937) and description of a new species of Eleutherodactylus from Mato Grosso, Brazil (Amphibia, Anura, Leptodactylidae). Proc Biol Soc Wash 112:1-18.

Howell WM and Black DA (1980) Controlled silver-staining of nucleolus organizer regions with a protective colloidal developer: 1-step method. Experientia 36:1014-1015.

Kaiser H (1996) Systematics and biogeography of Eastern Caribbean Eleutherodactylus (Anura, Leptodactylidae): Consensus from a multidisciplinary approach. In: Powell $\mathrm{R}$ and Henderson RW (eds) Contributions to West Indian Herpetology: A Tribute to Albert Schwartz. Ithaca, New York, pp 129-140.

Kaiser H, Green DM and Schmid M (1994) Systematics and biogeography of Eastern Caribbean frogs (Leptodactylidae, Eleutherodactylus), with the description of a new species from Dominica. Can J Zool 72:2217-2237.

Kaiser H, Dwyer CM, Feitchinger W and Schmid M (1995) A new species of Eleutherodactylus (Anura, Leptodactylidae) from Tobago, West Indies and its morphometric and cytogenetic characterization. Herpetol Nat Hist 3:151-163.

King M and Rofe R (1976) Karyotype variation in the Australian gekko Phyllodactylus marmoratus (Gray) (Gekkonidae, Reptilia). Chromosoma 54:75-87.

King M, Contrepas N and Honeycutt RL (1990) Variation within and between nucleolar organizer regions in Australian hylid frogs (Anura) shown by $18 \mathrm{~S}+28 \mathrm{~S}$ in situ hybridization. Genetica 80:17-29.

León PE (1970) Report of the chromosome numbers of some Costa Rica anurans. Rev Biol Trop 17:119-124.

Lourenço LB, Recco-Pimentel SM and Cardoso AJ (1998) Polymorphism of the nucleolus organizer regions (NORs) in Physalaemus petersi (Amphibia, Anura, Leptodactylidae) detected by silver staining and fluorescence in situ hybridization. Chromosome Res 6:621-628.

Lourenço LB, Garcia PCA and Recco-Pimentel SM (2003a) Restriction fragment analysis of the ribosomal DNA of Paratelmatobius and Scythrophrys species (Anura Leptodactylidae). Genet Mol Biol 26:139-143.

Lourenço LB, Garcia PC and Recco-Pimentel SM (2003b) Cytogenetics of a new species of the Paratelmatobius cardosoi group (Anura, Leptodactylidae) with the description of an apparent case of pericentric inversion. Amphibia-Reptilia 24:47-55

Lourenço LB, Bacci-Júnior N, Martins VG, Recco-Pimentel SM and Haddad CFB (2008) Molecular phylogeny and karyotype differentiation in Paratelmatobius and Scythrophrys (Anura, Leptodactylidae). Genetica 132:255-266.
Lynch JD (1980) A new species of Barycholos from Estado Goiás, Brasil (Amphibia, Anura, Leptodactylidae) with remarks on related genera. Bull Natl Mus Nat Hist 4:289-302.

Miyamoto MM (1983) Frogs of the Eleutherodactylus rugulosus group: A cladistic study of allozyme, morphological and karyological data. Syst Zool 32:109-124.

Miyamoto MM (1984) Central American frogs allied to Eleutherodactylus cruentus: Allozyme and morphological data. J Herpetol 18:256-263.

Savage JM and DeWeese JE (1979) A new species of Leptodactylidae frog, genus Eleutherodactylus, from the Cordillera de Talamanca, Costa Rica. Bull So Calif Acad Sci 78:107-115.

Savage JM and DeWeese JE (1980) The status of the Central American leptodactylid frogs Eleutherodactylus melanostictus (Cope) and Eleutherodactylus platyrhyncus (Günther). Proc Biol Soc Wash 93:928-942.

Savage JM and Myers CW (2002) Frogs of the Eleutherodactylus biporcatus group (Leptodactylidae) of Central America and Northern South America, including rediscovered, resurrected and new taxa. Am Mus Novit 3357:1-48.

Schmid M (1978) Chromosome banding in Amphibia I. Constitutive heterochromatin and nucleolus organizer regions in Bufo and Hyla. Chromosoma 66:361-388.

Schmid M, Feichtinger W, Wimer R, Mais C, Bolaños F and Leon $\mathrm{P}$ (1995) Chromosome banding in Amphibia XXI. Inversion polymorphism and nucleolous organizer regions in Agalychnis callidryas (Anura, Leptodactylidae). Cytogenet Cell Genet 69:18-26.

Siqueira S, Ananias F and Recco-Pimentel SM (2004) Cytogenetics of three Brazilian species of Eleutherodactylus (Anura, Leptodactylidae) with 22 chromosomes and re-analysis of multiple translocations in E. binotatus. Genet Mol Biol 27:363-372.

Siqueira S, Aguiar Jr O, Strüssmann C, Del-Grande ML and Recco-Pimentel SM (2008) Chromosomal analysis of three Brazilian "eleutherodactyline" frogs (Anura, Terrarana), with suggestion of a new species. Zootaxa 1860:51-59.

Sumner AT (1972) A simple technique for demonstrating centromeric heterochromatin. Exp Cell Res 75:304-316.

Wiley JE, Little ML, Romano MA, Blount DA and Cline GR (1989) Polymorphism in the location of the $18 \mathrm{~S}$ and $28 \mathrm{~S}$ rDNA genes on the chromosomes of the diploid-tetraploid treefrogs Hyla chrysoscelis and H. versicolor. Chromosoma 97:481-487.

Associate Editor: Yatiyo Yonenaga-Yassuda

License information: This is an open-access article distributed under the terms of the Creative Commons Attribution License, which permits unrestricted use, distribution, and reproduction in any medium, provided the original work is properly cited. 